\title{
BENTUK INSIDER TRADING SERTA IMPLEMENTASI MISAPPROPRIATION THEORY BAGI PELAKU INSIDER TRADING DI BURSA EFEK BERDASARKAN UNDANG-UNDANG NOMOR 8 TAHUN 1995 TENTANG PASAR MODAL
}

\author{
Daud Munasto ${ }^{1}$ dan Taun ${ }^{2}$ \\ ${ }^{1}$ Universitas Singaperbangsa Karawang Fakultas Hukum Prodi Ilmu Hukum \\ ${ }^{2}$ Universitas Singaperbangsa Karawang Fakultas Hukum Prodi Ilmu Hukum
}

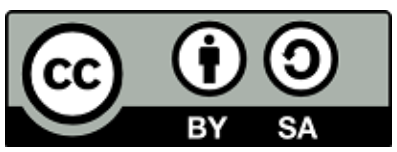

DOI: http://dx.doi.org/10.33603/hermeneutika.v3i2

Diterima: Juli 2020; Direvisi: 31 Agustus 2020; Dipublikasikan: Agustus 2020

\begin{abstract}
Abstrak: Bursa efek merupakan pihak yang menyelenggarakan dan menyediakan sistem dan atau sarana untuk mempertemukan penawaran dan permintaan efek pihak-pihak lain dengan tujuan memperdaagangkan efek diantara mereka. Efek yang diperjualbelikan dapat berupa saham, obligasi, reksadana atau produk derivatif lainnya. Untuk memberikan perlindungan hukum bagi masyarakat, perusahaan, dan pihak terkait lainnya pemerintah membuat Undang-undang Nomor 8 Tahun 1995 tentang Pasar Modal. Didalam pelaksanaan masih terdapat beberapa orang atau pihak mencoba mendapatkan keuntungan yang lebih besar dengan menggunakan akses yang mereka miliki melalui misappropriation theory sehingga membuat investor tidak nyaman dalam menjalankan transaksi jual beli efek.
\end{abstract}

Kata kunci: efek, misappropriation theory, insider trading

\author{
${ }^{1}$ Daud Munasto \\ Email : taun84@yahoo.com \\ ${ }^{2}$ Taun \\ Email : taun@fh.unsika.ac.id
}




\section{PENDAHULUAN}

Pasar modal sangat membantu dalam kemajuan perekonomian didalam suatu negara, pada dasarnya pasar modal merupakan salah satu bentuk investasi. Pasar modal (capital market) merupakan pasar untuk berbagai instrumen keuangan jangka panjang yang biasanya diperjualbelikan, baik dalam bentuk utang maupun modal sendiri. Instrumeninstrumen keuangan yang diperjualbelikan itu diantaranya adalah saham, obligasi, warant, right, obligasi konvertibel, dan berbagai produk turunan (derivatif) seperti opsi (put atau call). ${ }^{1}$

Sistem Pasar Modal diatur didalam Undang-Undang Nomor 8 Tahun 1995 tentang Pasar Modal, Undang-undang Pasar Modal dalam Pasal 1 angka (13) mendefinisikan Pasar Modal sebagai kegiatan yang bersangkutan dengan Penawaran Umum dan perdagangan Efek, Perusahaan Publik yang berkaitan dengan efek yang diterbitkannya, serta lembaga dan profesi yang berkaitan dengan Efek. ${ }^{2}$

Didalam Pasar Modal terdapat istilah insider trading, yaitu perdagangan efek yang dilakukan oleh mereka yang tergolong "orang dalam" perusahaan (dalam artian yang luas), perdagangan mana didasarkan atau dimotivasi karena adanya suatu "informasi orang dalam" (inside information) yang penting dan belum terbuka untuk umum, dengan perdagangan mana, pihak pedagang insider tersebut mengharapkan akan mendapatkan keuntungan ekonomi secara pribadi, langsung atau tidak langsung, atau yang merupakan keuntungan jalan pintas (short swing profit). ${ }^{3}$

Didalam pelaksanaan masih terdapat beberapa orang atau pihak mencoba mendapatkan keuntungan yang

\footnotetext{
1 Andrias Harefa, "Pasar Modal dan Transaksi Saham", (Jakarta: Rubrik EUREKA/Edukasi dan Ulasan Perencanaan Keuangan/Redaksi Sinar Harapan, 2002), hal. 4.

2 Pasal 1 angka (13) Undang-Undang Nomor 8 Tahun 1995 tentang Pasar Modal

${ }^{3}$ Munir Fuady, Pasar Modal Modern (Tinjauan Hukum), Jakarta: Menara Kuningan, 2010, hal. 167.
}

lebih besar dengan menggunakan akses yang mereka miliki melalui misappropriation theory sehingga membuat investor tidak nyaman dalam menjalankan transaksi jual beli efek. Maka perlu diketahui kaitan dengan bentukbentuk insider trading di bursa efek berdasarkan undang-undang nomor 8 tahun 1995 tentang Pasar Modal, serta implementasi misappropriation theory bagi pelaku insider trading di bursa efek berdasarkan undang-undang nomor 8 tahun 1995 tentang Pasar Modal.

\section{METODE PENELITIAN}

Rancangan ini menggunakan pendekatan yuridis normatif, yaitu jenis pendekatan yang mengkaji atau menganalisis data sekunder seperti bahan pustaka atau data sekunder yang terdiri dari bahan hukum primer, bahan hukum sekunder dan bahan hukum tersier. Bahanbahan tersebut disusun secara sistematis, dikaji kemudian dibandingkan dan ditarik kesimpulan dalam hubungannya dengan masalah yang diteliti.

Pendekatan penelitian yang digunakan dalam penelitian hukum ini yakni meliputi Statute Approach (Pendekatan Perundang-undangan) dan Conceptual Approach (Pendekatan Konsep).

Pendekatan Konsep atau Conceptual Approach dilakukan untuk mempelajari konsep-konsep terkait dengan misappropriation theory yang juga menjadi fokus dalam isu hukum terkait tema penelitian.

Pendekatan Perundang-undangan atau Statute Approach ialah pendekatan dengan menggunakan legislasi dan regulasi. ${ }^{4}$ Dalam penelitian ini pendekatan dilakukan dengan menelaah peraturan perundang-undangan maupun hukum positif yang berlaku di negara Indonesia

\footnotetext{
${ }^{4}$ Johnny Ibrahim, (2007), Teori dan Metodologi Penelitian Hukum Normatif, Malang: Bayumedia Publishing, Hlm. 57
} 
khususnya yang berkaitan dengan pasar modal yang juga menjadi fokus dalam isu hukum terkait tema penelitian.

Bahan hukum yang digunakan dalam penelitian ini adalah bahan hukum primer yaitu bahan hukum yang bersifat autoritatif artinya mempunyai otoritas, terdiri dari perundang-undangan, risalah pembuatan perundang-undangan dan putusan-putusan hakim. ${ }^{5}$ Bahan hukum primer dalam karya tulis ini yaitu UndangUndang Nomor 8 Tahun 1995 tentang Pasar Modal.

Bahan hukum sekunder, yaitu buku teks karena buku teks berisi prinsip-prinsip dasar ilmu hukum dan pandanganpandangan klasik para sarjana yang mempunyai kualifikasi tinggi. ${ }^{6}$ Literaturliteratur yang terkait permasalahan inilah yang masuk kualifikasi bahan hukum sekunder yang terkait permasalahan yang dikaji, antara lain: 1) Buku-buku hasil penelitian; 2) Pendapat dan doktrin para sarjana.

Bahan hukum tersier, yaitu bahan hukum yang memberikan penjelasan bahan hukum primer dan sekunder terutama mengenai istilah-istilah, yang terdiri dari :1) Kamus Hukum; 2) Kamus Besar Bahasa Indonesia; 3) Kamus Terjemahan Inggris-Indonesia.

\section{HASIL PENELITIAN}

Bentuk-Bentuk Insider Trading Di

\section{Bursa Efek}

Salah satu pelanggaran Pasar Modal yang diatur dalam UUPM adalah perdagangan orang dalam atau yang biasa dikenal dengan sebutan insider trading. Kegiatan insider trading bisa dideskripsikan sebagai "a case of insider trading in securities will usually involve the buying or selling of certain securities relating to a company by a person

\footnotetext{
${ }^{5}$ Ibid, hlm 141 .
}

${ }^{6} \mathrm{Ibid}, \mathrm{hlm} 142$. connected with that company, who in doing so, is in possession of specific information which relates to these securities and is not generally known but which would be likely, if made public to have a significant effect on the market price of the securities".?

Pada Undang-Undang Nomor 8 Tahun 1995 tentang Pasar Modal, tidak memberikan secara pasti definisi dari Insider Trading, namun diatur mengenai transaksi yang dilarang, yaitu orang dalam dari emiten yang mempunyai informasi orang dalam dilarang melakukan transaksi penjualan atau pembelian efek emiten atau perusahaan lain yang bertransaksi dengan emiten atau perusahaan publik yang bersangkutan8. Dengan demikian, dapat disimpulkan bahwa perdagangan efek yang dikategorikan sebagai praktek Insider Trading minimal harus memenuhi 3 unsur, yakni: ${ }^{8}$

1. Adanya orang dalam.

2. Informasi material yang belum tersedia bagi masyarakat belum disclosure (dipublikasikan).

3. melakukan transaksi karena informasi material tersebut.

Orang dalam sebagaimana dimaksud pada Pasal 95 UUPM meliputi: ${ }^{9}$

1. Komisaris, direktur atau pegawai perusahaan terbuka.

2. Pemegang saham utama perusahaan terbuka

Dari pengertian insider trading tersebut diatas, maka secara yuridis, diketemukan beberapa elemen dari suatu pranata hukum insider trading, yaitu sebagai berikut:

1. Adanya perdagangan efek.

\footnotetext{
Gil Brazier, Insider Dealing: Law \& Regulation, (London: Cavendish Publishing Limited, 1996), hal. 76.

8 Najib, Tinjauan Umum Terhadap Pasar Modal Indonesia, makalah diskusi pada mata kuliah Hukum Perusahaan, Program Magister Ilmu Hukum UII, 18 Januari 1997, hlm. 34

${ }^{9}$ Pasal 95 Undang-Undang Nomor 8 Tahun 1995 tentang Pasar Modal
} 
2. Dilakukan oleh orang dalam perusahaan.

3. Adanya inside information.

4. Inside information tersebut belum terbuka untuk umum.

5. Tujuannya untuk mendapat keuntungan yang tidak layak.

Insider trading memang berbahaya bagi suatu kehidupan pasar modal, membiarkan suatu insider trading hidup merajalela, sama saja seperti bunuh diri bagi pasar modal tersebut. Tetapi apa gerangan yang menjadi dasar pertimbangan sehingga perbuatan insider trading ini dilarang, bahkan dapat menjadi suatu perbuatan pidana. Kiranya banyak dasar pertimbangan untuk itu. Antara lain sebagai berikut: ${ }^{10}$

1. Insider Trading berbahaya bagi mekanisme pasar yang fair dan efisien, dapat diibaratkan bahwa jika suatu insider trading tidak dilarang, maka berjalannya pasar adalah seperti berjalannya suatu mobil tanpa minyak pelumas.

2. Insider Trading juga berdampak negatif bagi emiten, dengan adanya insider trading, pihak investor akan hilang kepercayaannya terhadap emiten itu sendiri. Dan, sekali nama baik investor jatuh, akan sulit baginya untuk berkembang atau menambah permodalan selanjutnya. Bahkan mungkin saja pihak pelaku insider trading tersebut berbuat hal-hal yang merugikan emiten agar harga berfluktuasi, sehingga dia dapat mengambil keuntungan dari situ.

3. Kerugian materil bagi investor, dengan terjadinya perbuatan yang digolongkan ke dalam insider trading ini, maka pihak investor akan mengalami kerugian secara langsung. Mungkin dia telah membeli surat berharga dengan harga yang kelewat murah. Bahkan

${ }^{10}$ Munir Fuady, op.cit, hal. 167. investor dapat dikatakan telah dikhianati atau dikibuli oleh pihak insider trader tersebut.

4. Kerahasiaan itu miliknya perusahaan, informasi rahasia itu miliknya perusahaan sesuai dengan asas pengakuan hak milik intelektual. Karena itu, tidaklah pada tempatnya milik perusahaan tersebut dimanfaatkan oleh pihak lain selain perusahaan itu sendiri.

Informasi orang dalam atau Insider Information adalah satu unsur penting dari praktik Insider Trading. Informasi merupakan komponen yang amat penting dalam berinvestasi. Dengan informasi, para investor akan dapat memutuskan akan membeli, menjual, atau menahan sahamsahamnya (atau efek lainnya). ${ }^{11}$

Inside information sebagai suatu yang merupakan kejadian dalam perusahaan (corporate affairs) yang belum terbuka untuk umum, di mana pihak "officers" dari perusahaan yang bersangkutan telah terlebih dahulu mengetahui informasi tersebut. ${ }^{12}$

Berdasarkan Peraturan Bapepam Nomor XI.C.1 tentang Transaksi Efek yang Tidak Dilarang Bagi Orang Dalam, ada beberapa transaksi efek yang tidak termasuk ke dalam kategori insider trading yakni:

1. Transaksi tersebut dilakukan antar orang dalam emiten yang sama yang mempunyai informasi yang sama yang dilaksanakan di luar bursa.

2. Transaksi tersebut dilakukan antar orang dalam yang mempunyai informasi orang dalam dengan pihak lain yang dilaksanakan di luar bursa, dengan syarat :

a. Orang dalam dimaksud telah memberikan seluruh informasi

\footnotetext{
11 Hamud M. Balfas, Hukum Pasar Modal Indonesia, (Jakarta : PT Tatanusa), hal. 438.

12 Jack P. Friedman. Dictionary of Business Terms, (Baron"s Educational Series, Inc : New York, 1987), hal. 288.
} 
orang dalam kepada pihak lain tersebut.

b. Pihak lain yang dimaksud tidak menggunakan informasi orang dalam yang diberikan untuk transaksi selain dengan orang dalam tersebut,.

c. Hal ini disertai dengan pernyataan tertulis bahwa pihak lain tersebut akan merahasiakan informasi orang dalam tersebut dan tidak akan melakukan transaksi selain dengan orang dalam dimaksud, dan

d. Pihak lain tersebut juga tidak akan melakukan transaksi efek emiten/perusahaan publik/ perusahaan lain yang melakukan transaksi dengan emiten atau perusahaan publik dimaksud dalam jangka waktu 6 bulan sejak informasi diterima.

Salah satu syarat yang harus dipenuhi agar terjadinya suatu insider trading adalah terjadinya suatu perdagangan (trading). Sehingga apabila seseorang mempunyai informasi orang dalam tetapi belum diperdagangkan, belumlah dapat dikatakan telah melakukan insider trading, tetapi mungkin telah melanggar kewajiban disclosure. ${ }^{13}$

Menurut Pasal 95, 96 dan 97 Undang-Undang Nomor 8 Tahun 1995 tentang Pasar Modal yang termasuk trading yang dilarang adalah: (tetapi dalam hal ini bapepam dapat membuat pengecualiannya, vide Pasal 99). ${ }^{14}$

1. Orang dalam yang melakukan pembelian atau penjualan atas:

a. Efek perusahaan di mana informasi berasal.

${ }^{13}$ Munir Fuady, op.cit, hal 171.

${ }^{14}$ Pasal 95, 96 dan 97 Undang-Undang Nomor 8 Tahun 1995 tentang Pasar Modal b. Efek perusahaan lain yang melakukan transaksi dengan perusahaan terbuka tersebut.

2. Orang dalam yang mempengaruhi pihak lain untuk melakukan pembelian atau penjualan atas efek tersebut.

3. Orang dalam yang memberi informasi orang dalam kepada pihak lain manapun yang patut diduga dapat menggunakan informasi tersebut untuk melakukan pembelian atau penjualan efek,

4. Orang lain yang secara melawan hukum memperoleh informasi orang dalam dari orang dalam tersebut lalu digunakannya dengan cara-cara seperti tersebut dalam point 1, 2 dan 3 tersebut.

5. Orang lain yang secara melawan hukum memperoleh informasi orang dalam secara tidak melawan hukum, tetapi penyediaan informasi tersebut dengan pembatasan-pembatasan (misalnya dengan kewajiban merahasiakan), kemudian menggunakan informasi tersebut dengan cara- cara seperti dimaksud dengan point 1, 2 dan 3 tersebut.

6. Perusahaan efek yang memiliki informasi orang dalam dari suatu perusahaan terbuka yang melakukan transaksi seperti dimaksud dalam point 1,2 dan 3 tersebut, kecuali terpenuhi dua syarat sebagai berikut:

a. Transaksi dilakukan bukan atas tanggungan sendiri, tetapi atas perintah nasabah, dan

b. Perusahaan efek tersebut tidak memberikan rekomendasi kepada nasabahnya mengenai efek yang bersangkutan.

Sebenarnya masih ada pihak lain selain yang disebut dalam Undang-Undang Nomor 8 Tahun 1995 tentang Pasar Modal 
yang mestinya masih mungkin dan pantas dijerat dengan perbuatan insider trading ini, yaitu pihak lain yang menerima informasi dari insider (tidak secara melawan hukum) yang masih belum masuk kategori persyaratan "dengan pembatasan" sebagaimana dimaksud point 5 diatas (Pasal 97 ayat (2) Undang-Undang Nomor 8 Tahun 1995 tentang Pasar Modal), bahkan mungkin hanya pasif saja dalam menerima informasi tersebut tetapi kemudian digunakan dalam artian trading. Ingat bahwa Undang-Undang Nomor 8 Tahun 1995 tentang Pasar Modal menggunakan kata-kata "berusaha untuk memperoleh informasi" bagi pihak lain, yang berarti pihak lain tersebut harus aktif dan inisiatif untuk mendapatkan informasi tersebut mesti berasal dari pihak lain tersebut. Misalnya apa yang disebut sebagai Tippee, baik yang aktif mencari informasi, ataupun yang pasif menerima melakukan trading dalam pengertian insider trading. Sementara yang dilarang oleh Undang-Undang Nomor 8 Tahun 1995 tentang Pasar Modal hanyalah pihak tippee yang aktif dan dengan inisiatifnya sendiri mencari informasi, di mana:

1. Informasi tersebut dicari dengan jalan melanggar hukum, seperti dengan mencuri, membujuk, kekerasan atau ancaman, atau

2. Informasi tersebut disertai dengan pembatasan-pembatasan (seperti kewajiban merahasiakan).

Bahkan semestinya selain tippee tersebut (aktif atau pasif), apa yang disebut secondaryt tippee pun pantas dilarang. Secondary tippee adalah pihak lain yang menerima informasi bukan langsung dari orang dalam tetapi melalui tippee yang lain. ${ }^{15}$

\section{Impelementasi Misappropriation Theory Bagi Pelaku Insider Trading Di Bursa Efek}

Pada pengaturan pasar modal Indonesia, praktek insider trading banyak dilandasi oleh adanya hubungan fiduciary duty antara pelaku dengan perusahaan tempat ia bekerja dan mendapatkan akses kepada informasi orang dalam. Akan tetapi dalam beberapa Pasal dalam UndangUndang Nomot 8 Tahun 1995 tentang Pasar Modal, dapat diperhatikan bahwa sesungguhnya pembuat undang-undang tersebut mempunyai maksud untuk mencakup pihak selain "orang dalam" sebagaimana dijabarkan pada Pasal 95 Undang-Undang Nomor 8 Tahun 1995 tentnag Pasar Modal. Pihak tersebut adalah pihak yang bukan merupakan orang dalam yang mendapatkan informasi orang dalam dari insider atau yang biasa disebut dengan tippee. $^{16}$

Pengaturan pada Pasal 97 ayat (1) dan (2) Undang-Undang Nomor 8 Tahun 1995 tentang Pasar Modal, adalah sebagai berikut:

1. Jika tippe berusaha untuk mendapatkan informasi orang dalam dan berhasil mendapatkannya dengan perbuatan yang melawan hukum31, maka ia dapat dikenakan larangan sebagaimana dimaksud pada Pasal 97 ayat (1) Undang-Undang Nomor 8 Tahun 1995 tentang Pasar Modal.

2. Jika tippe berusaha untuk mendapatkan informasi orang dalam dan berhasil mendapatkannya tanpa melakukan perbuatan melawan hukum, namun mendapat pembatasan dari emiten maka ia dilarang untuk melakukan transaksi efek berdasarkan informasi tersebut. Hal ini diatur dalam Penjelasan Pasal 97 ayat (2) Undang-Undang Nomor 8 Tahun tentang Pasar Modal. Pembatasan tersebut berarti bahwa emiten memberikan informasi tersebut dengan syarat untuk menjaga kerahasiaan informasi tersebut. Sehingga transaksi efek yang dilakukan berdasarkan informasi 
tersebut merupakan pelanggaran dari Pasal 97 ayat (2) dan dikenakan larangan berdasarkan Pasal 95 dan 96 Undang-Undang Nomor 8 Tahun tentang Pasar Modal. Dapat diartikan juga bahwa hal yang sama berlaku dalam hal insider yang memberikan informasi tersebut kepada tippee.

3. Jika tippe berusaha mendapatkan informasi orang dalam tanpa melakukan perbuatan melawan hukum dan tidak mendapat pembatasan dari emiten maka ia boleh melakukan transaksi efek berdasarkan informasi tersebut, tanpa dikenakan larangan seperti halnya pada Pasal 95 dan 96 Undang-Undang Nomor 8 Tahun tentang Pasar Modal. Hal ini disebabkan karena informasi tersebut berarti sudah bersifat publik dan semua pihak berhak mendapatkannya.

Berdasarkan poin-poin di atas maka dapat dilihat bahwa untuk menjadi pihak tippee yang diatur dalam UndangUndang Nomor 8 Tahun tentang Pasar Modal, perlu adanya "usaha" dari tippee itu sendiri dalam mendapatkan informasi orang dalam, baik dengan perbuatan melawan hukum atau tidak. Dari situ muncul kelemahan pada pengaturan mengenai insider atau pihak yang dilarang untuk melakukan transaksi efek. Kelemahan tersebut adalah tidak diaturnya mengenai tippee yang mendapat informasi orang dalam secara pasif (tidak melakukan usaha).

Bilamana dikaitkan dengan teori penyalahgunaan (misappropriation theory). Teori ini digunakan untuk menentukan siapa-siapa saja yang dapat dikategorikan sebagai insider. Penjelasan teori ini sehubungan dengan ketentuan dalam Undang-Undnag Nomor 8 Tahun 1995 tentang Pasar Modal belum menganut teori penyalahgunaan (misaproprition theory) dalam menentukan orang dalam (insider) tetapi masih menganut teori hubungan kepercayaan (fiduciary duty theory). ${ }^{17}$

Menurut teori penyelahgunaan masyarakat luas juga dapat dikategorikan sebagai insider sekalipun seseorang hanya berprofesi sebagai guru, dokter, petani, nelayan, dan lain-lain tanpa terkecuali. Teori penyelahgunaan (misappropriation theory) memandang, setiap orang yang menggunakan inside information atau informasi yang belum tersedia untuk publik melakukan perdagangan saham atas informasi tersebut dikategorikan sebagai insider. Walaupun orang yang melakukan perdagangan itu tidak mempunyai fiduciary duty dengan perusahaan. ${ }^{18}$

Definisi dari misappropriation theory yang diberikan oleh Black ${ }^{\text {ee }}$ Law adalah "the doctrine that a person who wrongfully uses confidential information to buy or sell securities in violation of a duty owed to the one who is the information source is guilty of securities fraud. ${ }^{19}$ The Misappropriation Theory memberikan pengertian yang lebih luas mengenai pihak yang dilarang untuk melakukan transaksi efek berdasarkan informasi orang dalam. Tolak ukurnya adalah terdapat penyalahgunaan informasi yang belum tersedia bagi masyarakat yang diperoleh dari orang lain untuk melakukan transaksi efek. ${ }^{20}$

Najib A. Gisymar mengartikan misappropriation theory sebagai teori mengenai transaksi yang dilakukan oleh orang luar perusahaan secara tidak sengaja berdasarkan informasi yang belum tersedia bagi masyarakat, maka dianggap sama dengan telah melakukan insider trading. ${ }^{21}$

\footnotetext{
17 Bismar Nasution, Keterbukaan Dalam....Op.cit., hal. 255.

${ }^{18}$ Ibid., hal. 264.

19 "Misappropriation theory", Blackes Law Dictionary 8th ed., ed. Bryan A. Garner (St. Paul-Minnesota: Thomson West, 2004).

${ }^{20}$ Najib A. Gisymar, op.cit, hal. 43.

${ }^{21}$ Ibid, hal. 42.
} 
Teori ini sangat komprehensif, karena dapat menjangkau praktek transaksi efek yang dilakukan oleh seseorang berdasarkan informasi secara tidak langsung atau dengan kata lain, dapat diterapkan kepada pihak yang mendapat "tip" dari orang dalam.

Berdasarkan pengertian tersebut, dapat dijabarkan unsur-unsur dari misappropriation theory, yaitu adanya:

1. Informasi material yang belum didisclose kepada masyarakat.

2. Transaksi efek yang dilakukan berdasarkan informasi tersebut.

3. Keuntungan pribadi yang didapat oleh pihak yang melakukan transaksi.

Berdasarkan teori ini, pihak yang mendapat tip dari orang dalam (tippee) dapat dikategorikan sebagai pelaku Insider Trading, jika ia melakukan transaksi efek berdasarkan informasi orang dalam tersebut. Bilamana orang dalam tersebut sudah secara jelas memberitahukan kepada tippee untuk merahasiakan informasi tersebut (seperti hubungan antara perusahaan dengan konsultan hukumnya), maka tippee sudah jelas mempunyai duty untuk merahasiakan informasi tersebut. Jika tidak diberitahukan secara jelaspun, sang tippee tetap dapat dikenakan sanksi atas insider trading berdasarkan misappropriation theory.

Dapat dikatakan bahwa misappropriation theory menjangkau pihak-pihak yang tidak terjangkau oleh teori fiduciary duty atau dapat dikatakan juga bahwa semua orang (baik orang dalam maupun orang luar) mempunyai kewajiban untuk menjaga kerahasiaan suatu informasi material yang belum diumumkan kepada masyarakat luas mengenai efek dan tidak melakukan transaksi efek berdasarkan informasi tersebut. ${ }^{22}$

Teori ini mulai dikenal setelah kasus Chiarella v. United States. Chiarella

22 Velliana Tanaya, Dicky Winata, Penerapan The Misappropriation Theory Dalam Pengaturan Insider Trading Di Indonesia, Jurnal, 2015 hal. 14. adalah orang yang bekerja di perusahaan percetakan yang mendapat pekerjaan untuk mencetak dokumen-dokumen yang berasal dari lima buah perusahaan yang akan melakukan penawaran pengambilalihan perusahaan. ${ }^{23}$

Meskipun dokumen tersebut diberikan kepada dengan nama yang palsu (untuk menjaga kerahasiaan informasi), Chiarella ternyata tetap dapat mengetahui nama dari ke-5 perusahaan tersebut. Berdasarkan informasi yang masih belum diumumkan kepada masyarakat tersebut, ia kemudian melakukan transaksi efek dan mendapat keuntungan yang besar.

Terhadap tindakan tersebut, pemerintah setempat menekankan tuntutannya terhadap Chiarella berdasarkan Section 10b-5 kepada dua keadaan, yaitu: ${ }^{24}$

1. Chiarella telah menyalahgunakan informasi penting yang berasal dari pelanggan Pandick (nama dari perusahaan percetakan tempatnya bekerja) yang akan melakukan pengambilalihan perusahaan lain; dan

2. Chiarella telah melakukan penipuan terhadap pelanggan Pandick tersebut.

Chiarella menyalahgunakan informasi yang diterimanya tersebut untuk keuntungan pribadinya, tanpa terlebih dahulu memberitahukan kepada masyarakat, sehingga masyarakat yang menjual saham perusahaan target merasa tertipu karena tidak mengetahui informasi sebelumnya. Mahkamah Agung menolak pendapat mengenai misappropriation theory. Hal ini disebabkan karena tidak disampaikannya masalah teori tanggung jawab tersebut kepada para juri. Juri akhirnya memerintahkan agar Chiarella dihukum hanya karena ia tidak membuka informasi material yang dia dapatkan

\footnotetext{
${ }^{23}$ Najib A. Gisymar, op.cit, hal. 58.

${ }^{24}$ Donald. C Langervoort, Insider Trading Regulation (Tennessee: Clark Boardman Company, 1989), hal. 48, sebagaimana dikutip oleh Najib A. Gisymar, op cit, hal. 59.
} 
kepada masyarakat atau kepada pihak yang menjual sahamnya (saham perusahaan target) kepadanya. ${ }^{25}$

Maka sebenarnya teori tersebut dapat menjangkau semua pihak, baik itu insider sebagaimana dimaksud pada Pasal 95 Undang-Undang Nomor 8 Tahun tentang Pasar Modal, maupun pihak ketiga seperti pada Pasal 97 ayat (1) dan (2) Undang-Undang Nomor 8 Tahun tentang Pasar Modal. Oleh karena itu dengan merujuk unsur-unsur misappropriation theory sebagaimana diuraikan di atas, maka unsur apakah adanya usaha atau tidak dari tippee untuk mendapatkan informasi orang dalam tidak diperhitungkan lagi. Penentu apakah ia dapat digolongkan sebagai pelaku insider trading atau tidak adalah apakah kemudian ia melakukan transaksi efek dengan informasi tersebut dan mendapat keuntungan dari transaksi tersebut. Dengan demikian, inti dari teori tersebut adalah adanya penyalahgunaan informasi, yakni informasi orang dalam (yang masih bersifat rahasia) digunakan untuk kepentingan pribadi atau beberapa pihak tertentu yang mendapatkan informasi tersebut. Informasi material tersebut sebenarnya adalah bersifat wajib untuk dibuka kepada masyarakat. Hal ini sesuai dengan prinsip keterbukaan, sehingga dengan informasi tersebut para pemegang saham atau calon investor dapat mempertimbangakan apakah akan membeli atau menjual saham dari emiten yang dimaksud, atau tidak bertransaksi efek dari efek yang dikeluarkan oleh emiten itu. ${ }^{26}$

$$
\text { Apabila }
$$

diterapkan miasppropriation theory dalam UU No.8 Tahun 1995 tentang Pasar Modal akan membuat konsep insider menjadi sangat komprehensif dengan mengatur dalam undang-undang tersebut berlaku untuk setiap orang yang menggunakan informasi

\footnotetext{
${ }^{25}$ Najib A. Gisymar, op.cit, hal. 59.

${ }^{26}$ Velliana Tanaya, Dicky Winata, op.cit, hal. 17.
}

yang belum tersedia untuk publik (inside information) melakukan perdagangan saham atas informasi tersebut dikategorikan sebagai insider dalam insider trading. Sekalipun orang yang melakukan perdagangan saham tersebut tidak mempunyai hubungan kepercayaan dengan perusahaan, maka dapat ditentukan sebagai pelaku insider trading menurut teori penyalahgunaan. Orangorang di luar dari pada emiten atau perusahaan yang akan go public, investor atau pemodal, dan lembaga-lembaga penunjang dan lembaga swasta penunjang lainnya dikategorikan sebagai orang dalam (insider). ${ }^{27}$

\section{KESIMPULAN}

Dari hasil penelitian diatas dapat disimpulkan ada pihak lain selain yang disebut dalam Undang-Undang Nomor 8 Tahun 1995 tentang Pasar Modal yang mestinya masih mungkin dan pantas dijerat dengan perbuatan insider trading ini, yaitu pihak lain yang menerima informasi dari insider (tidak secara melawan hukum) yang masih belum masuk kategori persyaratan "dengan pembatasan" sebagaimana dimaksud point 5 di atas (Pasal 97 ayat (2) UndangUndang Nomor 8 Tahun 1995 tentang Pasar Modal), bahkan mungkin hanya pasif saja dalam menerima informasi tersebut tetapi kemudian digunakan dalam artian trading. Ingat bahwa UndangUndang Nomor 8 Tahun 1995 tentang Pasar Modal menggunakan kata-kata "berusaha untuk memperoleh informasi" bagi pihak lain, yang berarti pihak lain tersebut harus aktif dan inisiatif untuk mendapatkan informasi tersebut mesti berasal dari pihak lain tersebut. Misalnya apa yang disebut sebagai Tippee, baik yang aktif mencari informasi, ataupun

\footnotetext{
27 Tandi Pada Palayukan, Bismar Nasution, dkk, Analisis Terhadap Larangan Praktik Insider Trading Di Pasar Modal, USU Law Journal, Vol.II-No.2 (Nov-2013), hal. 96.
} 
yang pasif menerima melakukan trading dalam pengertian insider trading.

Bilamana dikaitkan dengan misappropriation theory, maka sebenarnya teori tersebut dapat menjangkau semua pihak, baik itu insider sebagaimana dimaksud pada Pasal 95 Undang-Undang Nomor 8 Tahun tentang Pasar Modal, maupun pihak ketiga seperti pada Pasal 97 ayat (1) dan (2) Undang-Undang Nomor 8 Tahun tentang Pasar Modal. Oleh karena itu dengan merujuk unsur-unsur misappropriation theory sebagaimana diuraikan di atas, maka unsur apakah adanya usaha atau tidak dari tippee untuk mendapatkan informasi orang dalam tidak diperhitungkan lagi. Penentu apakah ia dapat digolongkan sebagai pelaku insider trading atau tidak adalah apakah kemudian ia melakukan transaksi efek dengan informasi tersebut dan mendapat keuntungan dari transaksi tersebut.

\section{DAFTAR PUSTAKA}

\section{A. Buku}

Andrias Harefa, "Pasar Modal dan Transaksi Saham", Jakarta: Rubrik

$\begin{array}{lr} & \text { EUREKA/Edukasi dan } \\ \text { Ulasan } & \text { Perencanaan } \\ \text { Keuangan/Redaksi r Sinar } & \\ \text { Harapan, 2002. } & \\ \text { Fuady, Pasar Modal Modern }\end{array}$

Munir Fuady, Pasar Modal Modern (Tinjauan Hukum), Jakarta: Menara Kuningan, 2010.

Abdurrahman, A. Ensiklopedia Ekonomi Keuangan dan Perdagangan, Jakarta: PT Pradnya Paramita, 1991.

Sawidji Widoatmodjo, Pengetahuan Pasar Modal untuk Konteks Indonesia, Jakarta: PT Elex Media Komputindo, 2015.

Sumantoro, Aspek-Aspek Hukum dan Potensi Pasar Modal Di Indonesia, Jakarta: Ghalia Indonesia, 1998.

Gil Brazier, Insider Dealing : Law \& Regulation, London
Cavendish Publishing Limited, 1996.

Hamud M. Balfas, Hukum Pasar Modal Indonesia, Jakarta: PT Tatanusa.

Jack P. Friedman, Dictionary of Business Terms, Baron "es Educational Series, Inc: New York, 1987.

"Misappropriation theory", Black"s Law Dictionary 8th ed., ed. Bryan A. Garner, St. PaulMinnesota: Thomson West, 2004.

Donald. C Langervoort, Insider Trading Regulation, Tennessee: Clark Boardman Company, 1989.

Departemen Keuangan RI, Seluk Beluk Pasar Modal, Jakarta: t.t..

Yayasan Mitra Dana, Penuntun Pelaku Pasar Modal Indonesia, Jakarta: 1991.

\section{B. Artikel Jurnal/Makalah}

Bismar Nasution, "Keterbukaan Dalam Perdagangan Saham di

Pasar Modal", Makalah

Disampaikan pada Seminar

Mengupas serta Mencermati

Fenomena Tindak Pidana di

Pasar Modal, pada Bina Manajemen Bisnis dan Investasi Dharma Nusantara, Jakarta, Tanggal 8 Mei 2003.

Bismar Nasution, "Aspek Hukum Dalam Transparansi Pengelolaan Perusahaan BUMN/BUMD Sebagai Upaya Memberantas KKN", Makalah Disampaikan pada Semiloka Peran Masyarakat (Stakeholder) melalui lembaga Pengawasan Pengelolaan Perusahaan Dalam Mendukung Pelaksanaan Good Corporate Governance Di Sumatera Utara, pada tanggal 30 April 2003. 
Najib, Tinjauan Umum Terhadap Pasar Modal Indonesia, makalah diskusi pada mata kuliah Hukum Perusahaan, Program Magister Ilmu Hukum UII, 18 Januari 1997.

Velliana Tanaya, Dicky Winata, Penerapan The Misappropriation Theory Dalam Pengaturan Insider Trading Di Indonesia, Jurnal, 2015.

Tandi Pada Palayukan, Bismar Nasution, dkk, Analisis Terhadap Larangan Praktik Insider Trading Di Pasar Modal, USU Law Journal, Vol.II-No.2 (Nov-2013).

\section{Perundang-Undangan}

Undang-Undang Nomor 8

Tahun 1995 tentang Pasar Modal.

Republik Indonesia Tahun 1995. 